\title{
Different levels of water deficit induces changes in growth pattern but not in chlorophyll fluorescence and water relations of Hancornia speciosa Gomes seedlings
}

Diferentes níveis de déficit hídrico induzem mudanças no padrão de crescimento, mas não nas relações hídricas e fluorescência de clorofila em mudas de Hancornia speciosa Gomes

\author{
E. C. da Silva ${ }^{*}$, T. B. Prado ${ }^{1}$, R. N. de Alcântara ${ }^{1}$, C. D. da Silva Junior ${ }^{2}$, L. C. \\ Nogueira ${ }^{3}$
}
${ }^{1}$ Departamento de Biologia/Laboratório de Fisiologia Vegetal/Centro de Ciências Biológicas e da Saúde, Universidade Federal de Sergipe, CEP 49100-000, São Cristóvão-Sergipe, Brasil
${ }^{2}$ Departamento de Biologia/Laboratório de Botânica Aplicada/ Centro de Ciências Biológicas e da Saúde, Universidade Federal de Sergipe, CEP 49100-000, São Cristóvão-Sergipe, Brasil
${ }^{3}$ Embrapa Tabuleiros Costeiros/ Av. Beira Mar, 3250, Aracaju, SE, Brasil.

*elizaciriaco@gmail.com

(Recebido em 02 de junho de 2015; aceito em 20 de janeiro de 2016)

\begin{abstract}
The tree Hancornia speciosa Gomes is commonly known in Brazil as "mangabeira", the fruit of which has high nutritional value. The knowledge about its physiology is still scarce, mainly during the initial phase of development. Thus, the aim of the present study was to evaluate the effects of different water deficit levels on growth pattern, chlorophyll fluorescence and water relations in H.speciosa seedlings. A factorial experimental design (water treatment $\mathrm{x}$ evaluation time) was used with four water treatments based on the field capacity (FC) $(80 \%, 60 \%, 40 \%$ and $20 \%)$ with five replications. Plant height, number of leaves, stem diameter, dry biomass production and partitioning, quantum efficiency of photosystem II (PSII), water potential $\left(\Psi_{\mathrm{w}}\right)$, relative water content (RWC), carbohydrates, proteins and proline content were analyzed. Severe water stress $(20 \%$ FC) led to a reduction in growth and altered the biomass partitioning pattern in the seedlings. However, water relations were not significantly affected, as the seedlings maintain high $\Psi_{\mathrm{w}}$ and RWC without significant increase in organic solutes content when cultivated in $20 \%$ FC. Moreover, the quantum efficiency of PSII was unaffected by the different water levels, suggesting a lack of photoinhibition due to water stress. The change in growth pattern, with an increase in root depth and reduction in shoot emission, seems to be the main strategy of the $H$. speciosa seedlings for the maintenance of tissue hydration throughout periods of water deficit.

Keywords: biomass partitioning, proline, root to shoot ratio
\end{abstract}

Hancornia speciosa Gomes é uma espécie conhecida popularmente no Brasil como mangabeira, cujo fruto apresenta alto valor nutricional. O conhecimento sobre a sua fisiologia é ainda escasso, principalmente no que se refere ao desenvolvimento inicial. Dessa forma, o objetivo do presente trabalho foi avaliar os efeitos de diferentes níveis de déficit hídrico sobre o padrão de crescimento, fluorescência de clorofila e relações hídricas em mudas de mangabeira. Foi utilizado um esquema fatorial (tratamentos x época de avaliação) com quatro tratamentos hídricos com base na capacidade de campo (CC) $(80 \%, 60 \%, 40 \%$ e $20 \%)$, com cinco repetições. Foram avaliados a altura das plantas, número de folhas, diâmetro do caule, produção e partição de biomassa, eficiência quântica do fotossistema II (PSII), potencial hídrico ( $\Psi$ w), teor relativo de água (TRA) e teor de carboidratos, proteínas e prolina. O déficit hídrico severo $(20 \%$ CC) levou a uma redução no crescimento e alterou o padrão de partição de biomassa nas mudas. No entanto, as relações hídricas não foram significativamente afetadas, pois as mudas mantiveram altos valores de $\Psi_{\mathrm{w}}$ e TRA, sem acúmulos significativos nos teores de solutos orgânicos quando cultivadas com $20 \% \mathrm{CC}$. Além do mais, a eficiência quântica do PSII não foi afetada pelos diferentes regimes hídricos, sugerindo que não houve fotoinibição devido ao estresse hídrico. A mudança no padrão de crescimento, com um incremento no aprofundamento das raízes e redução no crescimento da parte aérea parece ser a principal estratégia das mudas de $H$. speciosa para a manutenção da hidratação dos tecidos durante períodos de déficit hídrico. Palavras-chave: partição de biomassa, prolina, razão parte aérea/raiz 


\section{INTRODUCTION}

The "mangabeira" (Hancornia speciosa Gomes) is a small fruit tree found predominantly in tropical regions that produces a fruit known locally in Brazil as "mangaba". This tree belongs to the family Apocynaceae, which has about 400 genera and 3700 species, with 95 genera and 850 species occurring in Brazil [1]. The mangabeira is abundant on the coastal tablelands and coastal plains of the northeastern region of the country as well as the savanna-like cerrado region [2].

Mangabeira is of considerable economic importance in northeastern Brazil, especially in the state of Sergipe, which is the largest producer in Brazil $[2,3]$. The cultivation of the mangabeira occurs mainly with a low degree of technology, as manual harvesting is carried out in locations of spontaneous occurrence [3]. However, these sites have been threatened by real estate and livestock interests, which have led to the replacement of native vegetation [2].

In summer, locations of the natural occurrence of the mangabeira experience drought due to scarce rainfall and high temperatures. As plant yield depends on the availability of water in the soil, drought affects all physiological processes vital to plant development when not counterbalanced by an efficient mechanism of tolerance [4]. Water participates in cell division and elongation, is responsible for the sustenance of herbaceous plants, assists in nutrient input and transport through the xylem and phloem and is associated with metabolic reactions [5]. Water also affects photosynthesis, thus, insufficient water availability leads to a reduction in stomatal conductance, with consequent reductions in transpiration and gas exchange $[6,7]$.

Drought tolerance in plants can be raised by physiological mechanisms that enable them to conserve water, such as stomatal closure at the hottest time of the day, or morphological changes, such as water reservoirs in the roots or trunk and the shedding or absence of leaves, which helps reduce water loss through transpiration $[7,8,9]$.

Plants classified as "drought tolerant" generally have mechanisms of adjustment, especially when stress occurs in a gradual fashion. One of them is the osmotic adjustment which can occur by the accumulation of compatible organic solutes and inorganic ions within their cells to make the cellular water potential lower than that of the surrounding soil, thereby maintaining water inflow and turgor pressure $[6,10,11,12]$. These plants can also transfer nutrients and metabolic compounds from older to younger leaves to increase photosynthetic efficiency and reduce surface transpiration through the abscission of senescent leaves. Moreover, the anticipation of blossoming ensures the perpetuation of the species. These processes allow plants longer survival in the dry season, but are not sufficient in situations of prolonged drought beyond the capacity of tolerance of the species [6].

Plant responses to drought and its effects can be measured through plant growth, especially the production and distribution pattern of dry biomass, water status and the accumulation of osmoprotectants, which indicate osmotic regulation. Moreover, photosynthesis can be evaluated by quantifying levels of photosynthetic pigments, chlorophyll $a$ fluorescence and carbon assimilation [7, 13].

Chlorophyll fluorescence is a tool applied in water stress studies and has been widely applied. Fluorescence occurs when part of the energy incident in chlorophyll is dissipated by the emission of light. The fluorescence spectrum differs from the spectrum of absorbed light and the wavelength emitted is greater than that absorbed, which facilitates the measurement of fluorescence [13]. Generally, exposure to stress induces alterations in photobiological processes, resulting in stomatal limitations, such as restrictions in the supply of carbon dioxide and the loss of water vapor, and limitations to non-stomatal components, with harm caused to reaction centers of photosystems I and II (PSI and PSII), thereby compromising the photosynthesis efficiency [7, 14]. According to Bolhàr-Nordenkampf et al. (1989)[15], changes in the photochemical efficiency of plants under drought conditions may be assessed by the analysis of chlorophyll $a$ fluorescence associated with PSII, which provides important information for profiling the physiological behavior of species in response to water stress in the natural environment [7].

The initial phase of development (seedling) is the most critical to survival in the field. Considering the economic importance of the $H$. speciosa, the aim of the present study was to evaluate the effects of different levels of water deficit on the physiological behavior of seedlings 
for this species through the analysis of some growth parameters, water relations and chlorophyll $a$ fluorescence.

\section{MATERIAL AND METHODS}

\section{Plant material and experimental design}

The present study was conducted in a greenhouse of the Department of Biology of the Universidade Federal de Sergipe, Brazil. Hancornia speciosa Gomes seedlings were propagated using seeds from fruits collected from coastal plains with sandy soils in the municipality of Pirambu, state of Sergipe, northeastern Brazil. After emergence, the seedlings were transferred to polyethylene pots containing $6 \mathrm{~kg}$ of topsoil (organic substrate). The seedlings were acclimated for 15 days and irrigated daily at $80 \%$ substrate field capacity (FC).

A factorial experimental design (water treatment $\mathrm{x}$ evaluation time) was used with four water treatments, eight evaluation time and five replications. Based on a priori knowledge that the mangabeira does not grow well under $100 \% \mathrm{FC}$, the control group was defined as the plants watered with $80 \%$ FC. The water treatments were $80 \%, 60 \%, 40 \%$ and $20 \%$ FC, determined gravimetrically by the difference in the weight of the moist soil after being saturated through capillarity and the excess water drained by gravity [16]. Over a 60-day period, the pots were weighed daily and water was replaced based on the difference in weight and the respective percentages of FC in the different treatments. Control plants received water daily. The other treatments were irrigated only enough to establish the respective FC levels (Figure 1).

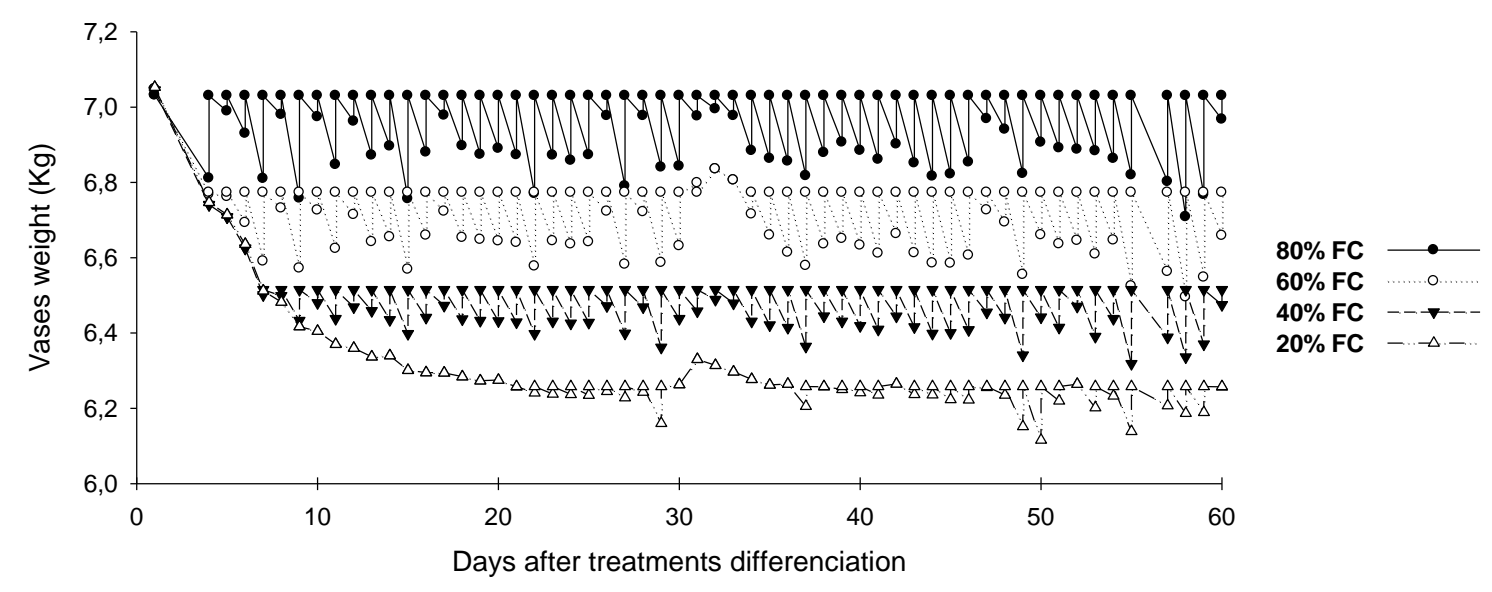

Figure 1: Water replacement in H. speciosa seedlings throughout daily weighing. Water stress treatments throughout experiment based on field capacity (80, 60, 40 and 20\% FC).

\section{Plant growth}

Plant growth was evaluated weekly for 60 days with the measurement of plant height and stem diameter using a digital caliper (Digimess Model, DIN 862) and counts of the number of leaves. After 60 days, the plants were harvested, separated into different organs, packed in paper bags and left to dry in an oven until reaching a constant weight. The quantification of dry mass was used to calculate the allocation of biomass and the shoot to root ratio.

\section{Determination of water potential and relative water content}

Due the small size of the leaves, after 60 days of treatment, the water potential $\left(\Psi_{\mathrm{w}}\right)$ of the branches was determined at midday using a Scholander pressure chamber (Model 3035, Soil Moisture Equipment Corp., Santa Barbara, CA, USA). Relative water content (RWC) was determined in six discs taken from the leaves. Fresh mass weight (FMW) was determined and the discs were placed in Petri dishes containing distilled water. After $24 \mathrm{~h}$ stored in a refrigerator in the dark, the discs were weighed again to obtain the turgid mass weight (TMW). The samples were then packed in paper bags and placed in an oven with forced air circulation at $70{ }^{\circ} \mathrm{C}$ for 48 
hours to obtain the dry mass weight (DMW). RWC was calculated using the equation described by Weatherley (1950) [17] and expressed as a percentage value as follows:

$$
\text { RWC }(\%)=[(\text { FMW-DMW }) /(\text { TMW-DMW })] \times 100 \text {. }
$$

Soluble sugars, proline, soluble protein and amino acids analysis

Biochemical analyses were performed colorimetrically. Samples consisted of approximately $0.2 \mathrm{~g}$ of leaf blade without the central vein collected at midday (the same leaves from water potential measurements). The specimens were wrapped in aluminum foil and frozen until the preparation of the extracts. The extracts were prepared by grinding the plant material in a mortar with $5 \mathrm{ml}$ of $0.1 \mathrm{M}$ monobasic phosphate buffer, $\mathrm{pH}$ 7, containing $0.01 \mathrm{M}$ EDTA and filtered on nylon mesh [18]. The solutions were then centrifuged at $8000 \mathrm{x} g$ for 10 minutes. The supernatants were transferred to $2 \mathrm{ml}$ Eppendorff tubes and frozen until analysis.

Soluble carbohydrate content was determined colorimetrically at $490 \mathrm{~nm}$ in a $0.5 \mathrm{~mL}$ aliquot of the extract using the phenol-sulfuric acid method, with D-(+)-glucose as the standard [19]. Proline was determined at $520 \mathrm{~nm}$ in a $1 \mathrm{~mL}$ aliquot of the extract, with ninhydrin as the specific reagent and pure proline as the standard [20]. Soluble proteins were determined at $595 \mathrm{~nm}$ using the dye binding method in a $0.1 \mathrm{~mL}$ aliquot of the extract, with pure bovine serum albumin as the standard [21].

\section{Chlorophyll fluorescence measurement}

Chlorophyll $a$ fluorescence measurements were taken weekly between 9 and 10 am using a saturating light pulse through a portable fluorometer (Handy PEA, Hansatech Instruments, Norfolk, UK) in mature fully expanded leaves exposed to direct sunlight. Selected leaves were submitted to a 30-min dark adaptation period, which was sufficient for all PSII reaction centers to become open [22]. Immediately following adaptation to the dark, the leaves were exposed to a pulse of saturating light at an intensity of $3000 \mu \mathrm{mol} \cdot \mathrm{m}^{-2} \cdot \mathrm{s}^{-1}$ with a wavelength of $656 \mathrm{~nm}$ for $1 \mathrm{~s}$. The evaluation of the kinetics of chlorophyll $a$ fluorescence was based on values of initial fluorescence (F0), maximum fluorescence (Fm), variable fluorescence (Fv) and quantum efficiency $(\mathrm{Fv} / \mathrm{Fm})$.

\section{Statistical analysis}

The data were submitted to analysis of variance and the means were compared using Tukey's multiple range test $(P<0.05)$.

\section{RESULTS}

Water deficit induced reduction in all growth parameters of $H$. speciosa seedlings. Significant differences $(P<0.05)$ among treatments were found in plant height, stem diameter and number of leaves over time (Figure $2 \mathrm{~A}, \mathrm{~B}$ and C). Plant height was lower after 30 days of water deficit in plants cultivated with $20 \%$ FC (severe stress) in comparison with those with $80 \%$ and $60 \%$ FC. Plants grown with $40 \%$ FC only exhibited a significant reduction in plant height in comparison to $60 \%$ FC plants after 52 days (Figure $2 \mathrm{~A}$ ).

Severe water deficit (20\% FC) induced a growth stoppage related to stem elongation, with no significant increase in plant height (Figure 2A). Contrary, plants grown with 60\% FC demonstrated a better performance in comparison to those grown with $40 \% \mathrm{FC}$ at 52 days and henceforth. 


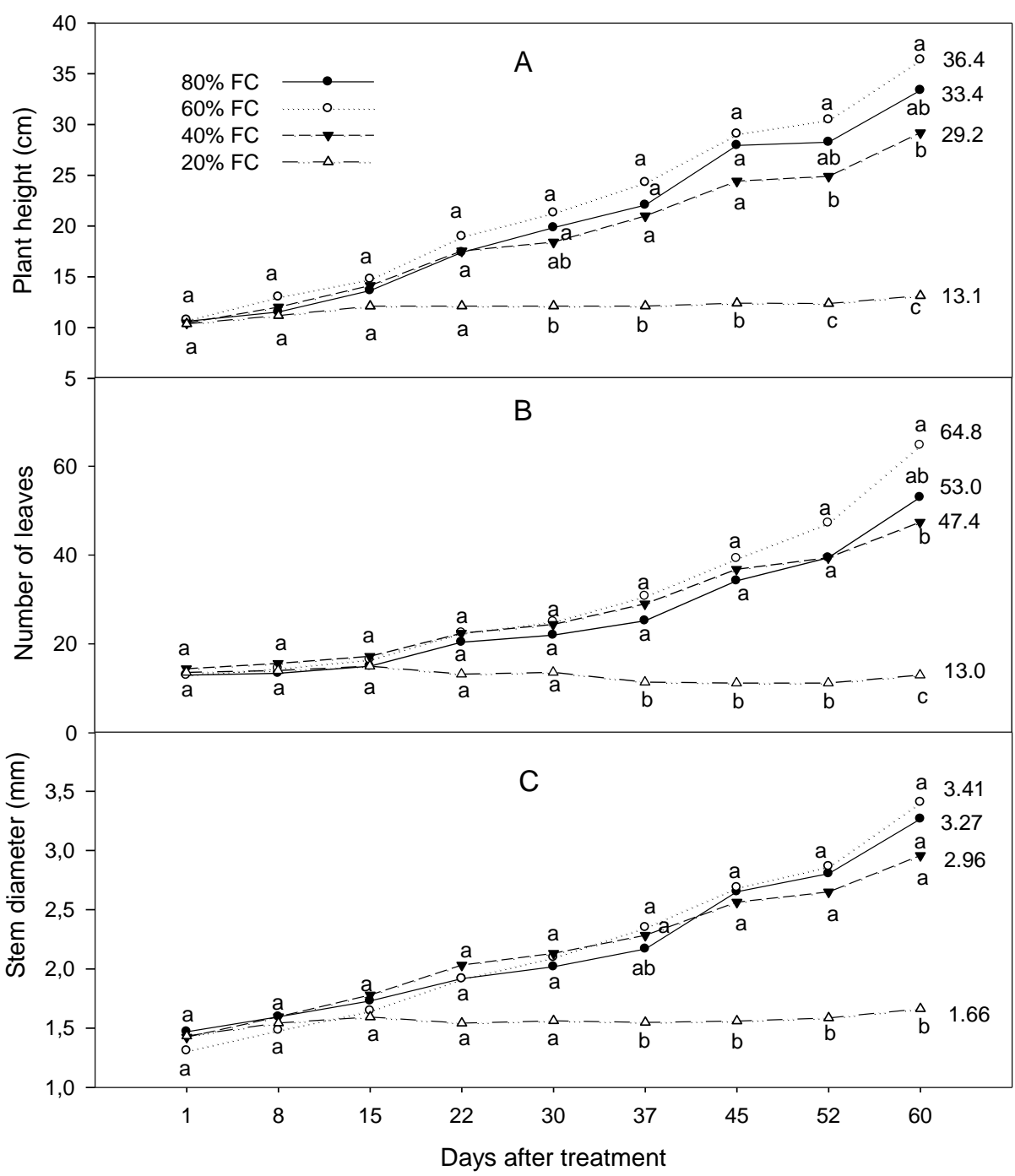

Figure 2: Plant height (A), number of leaves $(B)$ and stem diameter $(C)$ of $H$. speciosa seedlings cultivated under water deficit based on different degrees of field capacity (80, 60, 40 and $20 \%$ FC). Means followed by same letters do not differ significantly $(P<0.05$, Tukey's multiple range test).

The number of leaves was reduced in response to water deficit. Fewer leaves in comparison to the control were found on plants grown with 20\% FC beginning on Day 37. This was followed by shedding and the subsequent emission of new leaves at the end of the experimental period (Figure 2B). Mean values in this treatment remained lower than all other treatments and did not differ significantly from the beginning of the experimental period. Plants grown with $40 \% \mathrm{FC}$ had an average of 47.4 leaves, which was statistically similar to the control plants. In contrast, plants grown with $60 \% \mathrm{FC}$ had the best performance, with an average of 64.8 leaves at the end of the experiment (Figures $2 \mathrm{~A}$ and $2 \mathrm{~B}$ ).

Stem diameter was the least affected growth parameter, with a significant reduction only in plants cultivated with 20\% FC from Day 37 onward (Figure 2C).

Despite the differences in soil water availability (Figure 1), the dry matter of the stem and roots seems not to have been strongly affected by this stress factor, as no significant differences were found among treatments (Figure $3 \mathrm{~A}$ and B). In contrast, leaf dry matter (LDM) was affected by severe stress, demonstrating a statistically significant reduction $(P<0.05)$ in plants grown with $20 \%$ FC (Figure 3C). In the analysis of total dry matter, plants under 60\% FC demonstrated the best performance, with a tendency toward an increase in dry matter production in comparison to control plants, while plants under $20 \%$ FC exhibited a reduction in dry matter, differing significantly $(P>0.05)$ from plants under 60\% FC, but not from the control (Figure 3D). 

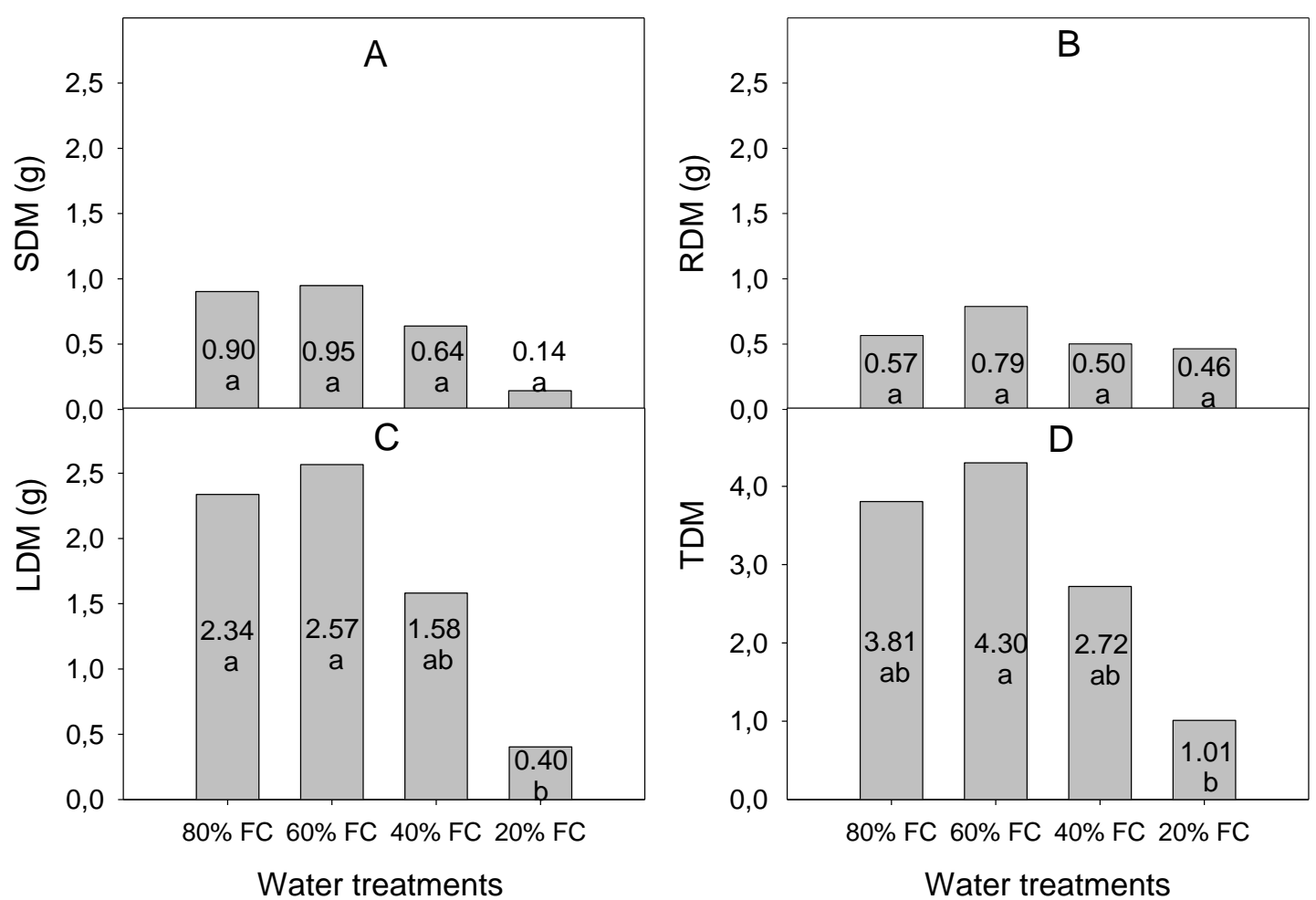

Figure 3: Stem (SDM), root (RDM), leaf (LDM) and total (TDM) dry matter (respectively $A, B, C$ and D) of $H$. speciosa seedlings cultivated under water deficit with different degrees of field capacity (80, 60, 40 and $20 \%$ FC). Means followed by same letters do not differ significantly $(P<0.05$, Tukey's multiple range test).

A change in the pattern of biomass partitioning was observed in plants under $20 \% \mathrm{FC}$ in comparison with the other treatments, with an increase in root dry matter in detriment to the shoot nearly threefold greater than that found in control plants (Figure $4 \mathrm{~A}$ ). The shoot to root ratio was significantly changed to $1: 1$ in plants under $20 \%$ FC, in comparison with about 5:1 in the control plants and 4:1 in the other treatments (Figure $4 \mathrm{~B}$ ), although these last treatments did not differ from control plants.
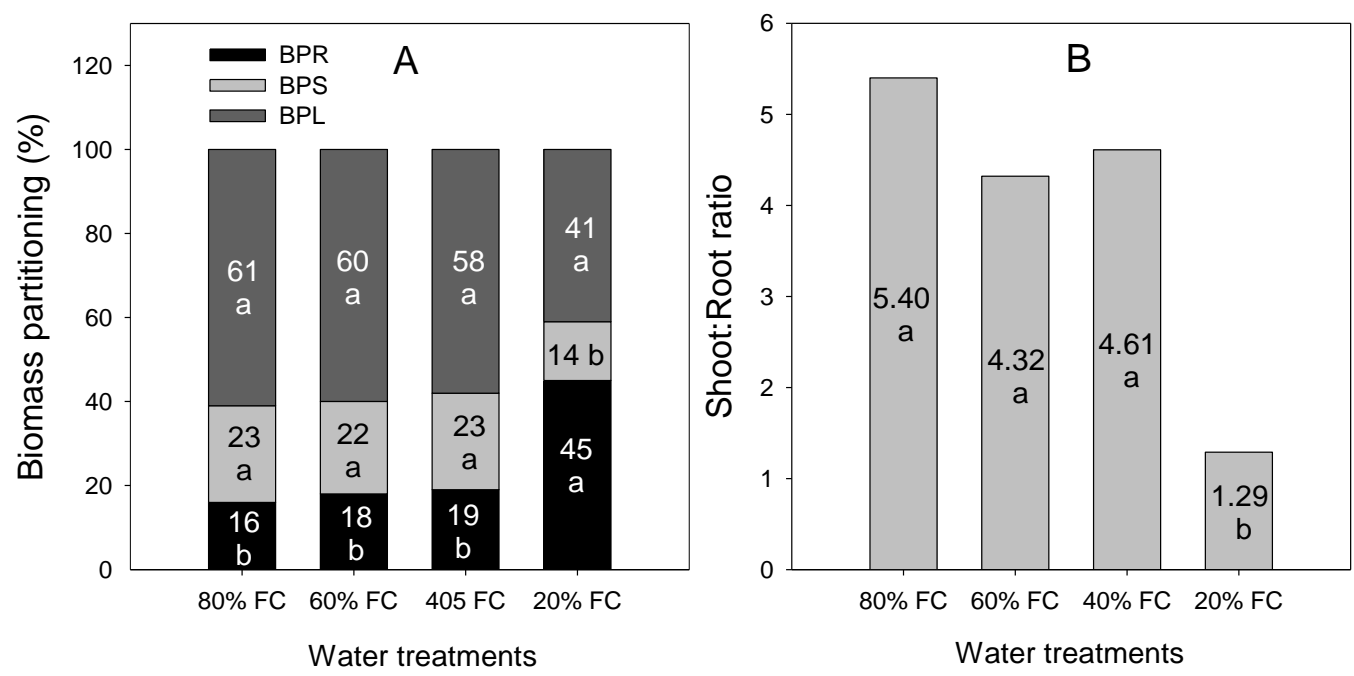

Figure 4: Biomass partitioning to roots (BPR), stem (BPS) and leaves (BPL) (A) and shoot to root ratio $(B)$ of $H$. speciosa seedlings cultivated under water deficit with different degrees of field capacity (80, 60, 40 and 20\% FC). Means followed by same letters do not differ significantly $(P<0.05$, Tukey's multiple range test). 
In contrast to the evident effects of drought on growth, little variation was found regarding water relations. No significant difference among treatments was found regarding RWC, which ranged from $73.4 \%$ in plants cultivated with $80 \%$ FC to $60.4 \%$ in plants grown with $20 \%$ FC (Figure 5A). Moreover, $\Psi_{\mathrm{w}}$ only differed between plants submitted to $40 \%$ and $20 \% \mathrm{FC}$, but not when compared to control plants. The lowest value was found in plants cultivated with $20 \%$ FC $(-0.12 \mathrm{MPa})$ and the highest was found in plants grown with 40\% FC (-0.06 MPa) (Figure 5B).
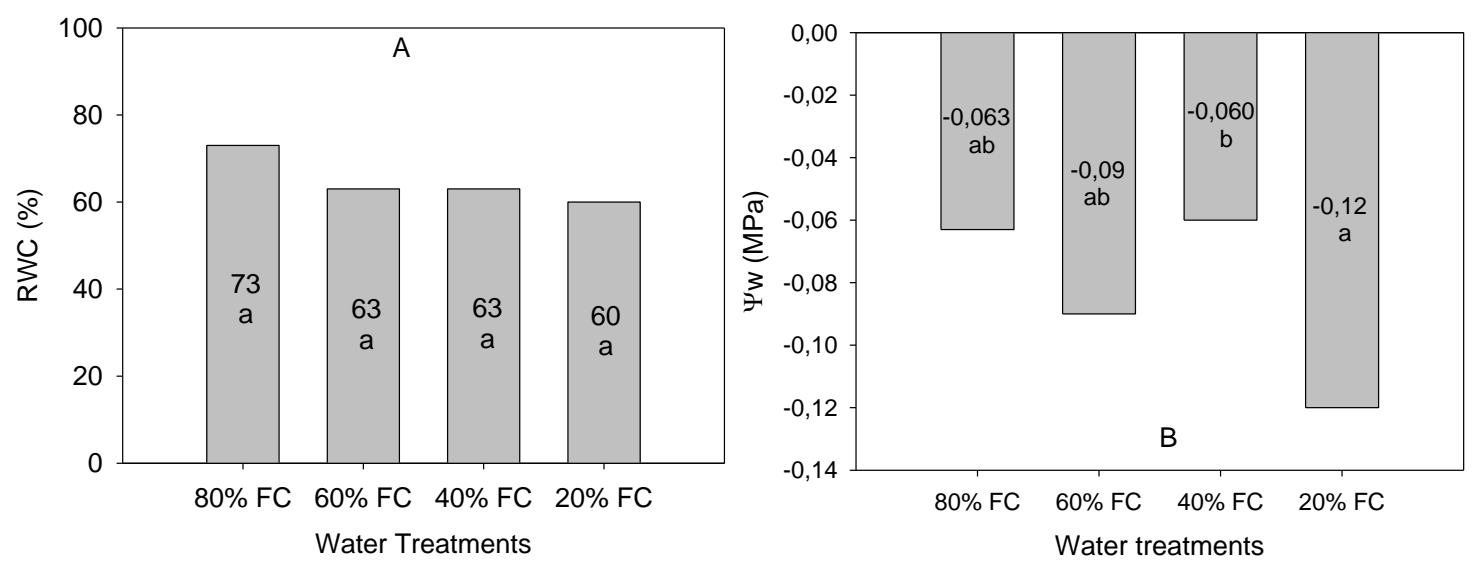

Figure 5: Relative water content $(R W C)(A)$ and branch water potential $(\Psi w)(B)$ of H.speciosa seedlings cultivated under water deficit with different degrees of field capacity (80, 60, 40 and 20\% FC). Means followed by same letters do not differ significantly $(P<0.05$, Tukey's multiple range test).

The biochemical analysis revealed little change in the accumulation of organic solutes in the leaves of $H$. speciosa seedlings. Moreover, none of the treatments demonstrated a significant accumulation of soluble proteins or carbohydrates (Figure 6). The variation in the amount of proteins (Figure 6A) and carbohydrates (Figure 6B) ranged from 16.24 to $21.43 \mathrm{mg}^{-g^{-1}} \mathrm{FM}$ and 225.09 to $343.44 \mu$ mol. $\mathrm{g}^{-1} \mathrm{FM}$, respectively. However, proline accumulation was found in plants grown with $60 \% \mathrm{FC}$ in comparison to control plants (Figure 6C). Moreover, plants grown with 40 and $20 \%$ FC also demonstrated a tendency toward the accumulation of proline, although the values did not differ significantly from the control plants. 


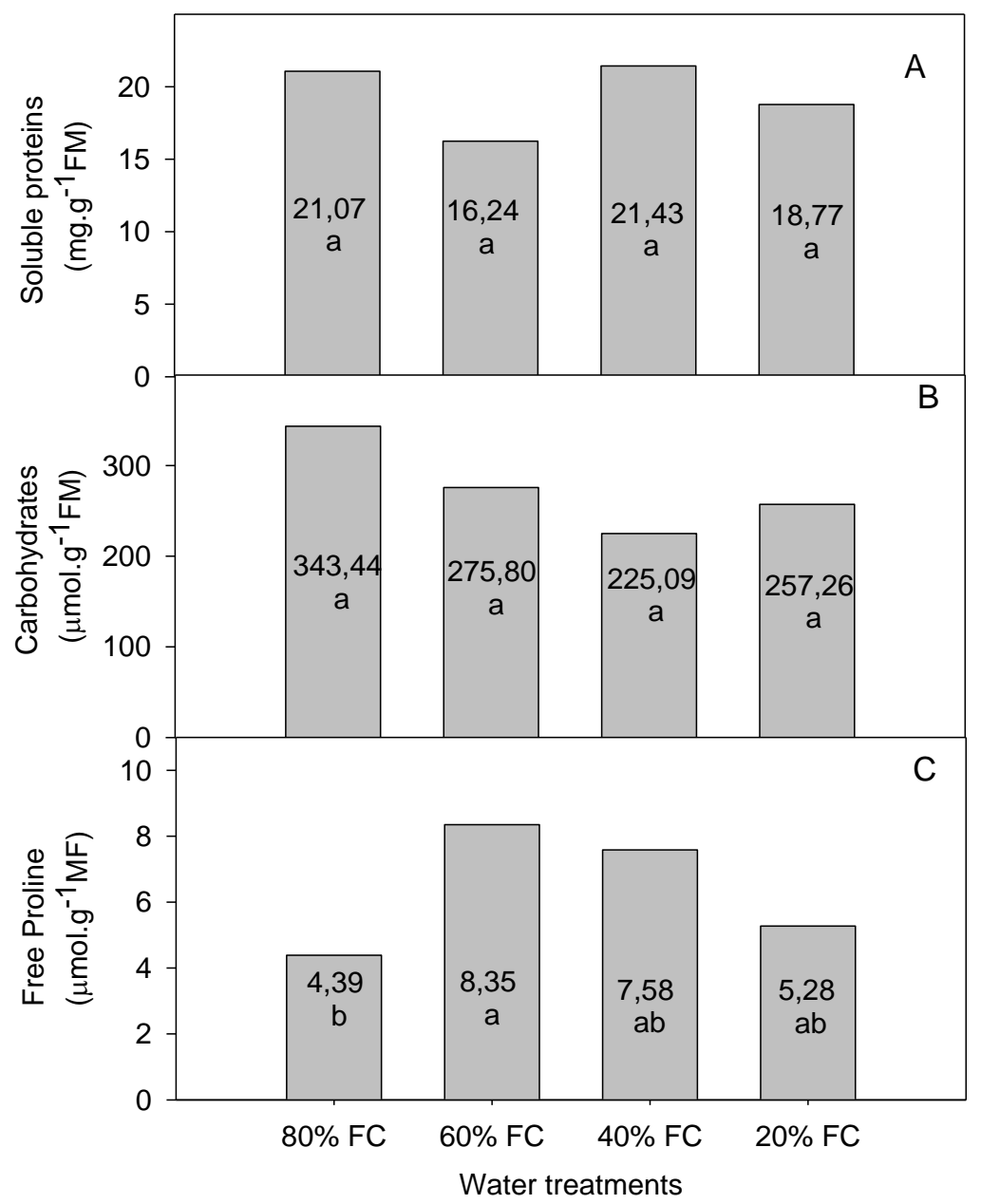

Figure 6: Soluble proteins $(A)$, carbohydrates $(B)$ and free proline $(C)$ content in $H$. speciosa seedlings cultivated under water deficit with different degrees of field capacity $(F C)$. Means followed by same letters do not differ significantly $(P<0.05$, Tukey's multiple range test).

Regarding chlorophyll $a$ fluorescence, no significant difference in initial fluorescence (F0) was found among treatments or over time (Table 1), except for a significant drop on Day 30, followed by a recovery. A $26 \%$ reduction in maximum fluorescence $(\mathrm{Fm})$ occurred in plants subjected to 20\% FC in comparison to the control group on Day 37 (Table 1). However, this difference did not persist through to the end of the experiment, as Fm recovered in the subsequent evaluations, reaching statistically similar values to those found in the other groups.

On Days 30 and 37, significant differences were found in variable fluorescence (Fv) and quantum efficiency $(\mathrm{Fv} / \mathrm{Fm})$ between plants submitted to $20 \% \mathrm{FC}$ in comparison to the other treatments (Table 1). Throughout the experiment, plants treated with $20 \%$ FC had quantum efficiency of 0.69 on Day 30, which is indicative of photoinhibition, rising thereafter to 0.74 and 0.76 on the two subsequent evaluations (Days 45 and 60). 
Table 1: Initial (FO), maximum $(F m)$ and variable chlorophyll a fluorescence $(F v)$ and quantum efficiency $(F v / F m)$ in $H$. speciosa seedlings grown under greenhouse conditions with different percentages of soil water availability. Equal lower case letters denote absence of significant difference comparing treatments and equal upper case letters denote absence of significant difference comparing evaluations $(P<0.05$,

Tukey's multiple range test).

\begin{tabular}{|c|c|c|c|c|c|c|c|c|}
\hline \multirow{3}{*}{$\begin{array}{l}\text { Water } \\
\text { degre } \\
\text { e (FC) }\end{array}$} & \multicolumn{8}{|c|}{ F0 } \\
\hline & \multicolumn{8}{|c|}{ Days of evaluation } \\
\hline & 1 & 8 & 15 & 22 & 30 & 37 & 45 & 60 \\
\hline $80 \%$ & $598.7 \mathrm{aA}$ & $573.5 \mathrm{aA}$ & $544.5 \mathrm{aA}$ & $544.2 \mathrm{aA}$ & $311.2 \mathrm{aB}$ & $537.2 \mathrm{aA}$ & $537.2 \mathrm{aA}$ & $530.2 \mathrm{aA}$ \\
\hline $60 \%$ & $639.7 \mathrm{aA}$ & $577.7 \mathrm{aA}$ & $591.5 \mathrm{aA}$ & $540.0 \mathrm{aA}$ & $369.2 \mathrm{aB}$ & $530.0 \mathrm{aA}$ & $534.5 \mathrm{aA}$ & $532.3 \mathrm{aA}$ \\
\hline $40 \%$ & $599.2 \mathrm{aA}$ & $560.2 \mathrm{aA}$ & $569.7 \mathrm{aA}$ & $541.7 \mathrm{aA}$ & $392.0 \mathrm{aB}$ & $546.2 \mathrm{aA}$ & $543.7 \mathrm{aA}$ & $529.2 \mathrm{aA}$ \\
\hline \multirow[t]{2}{*}{$20 \%$} & $575.5 \mathrm{aA}$ & $543.5 \mathrm{aA}$ & $577.7 \mathrm{aA}$ & $537.7 \mathrm{aA}$ & $404.5 \mathrm{aB}$ & $546.7 \mathrm{aA}$ & $548.5 \mathrm{aA}$ & $534.7 \mathrm{aA}$ \\
\hline & \multicolumn{8}{|c|}{ Fm } \\
\hline $80 \%$ & $2725 \mathrm{aA}$ & $2861 \mathrm{aA}$ & 2788 aA & $2912 \mathrm{aA}$ & $1522 \mathrm{aB}$ & $2903 \mathrm{aB}$ & 2909 aA & $2669 \mathrm{aA}$ \\
\hline $60 \%$ & $2880 \mathrm{aA}$ & $2841 \mathrm{aA}$ & $2942 \mathrm{aA}$ & $\begin{array}{l}2640 \\
\mathrm{aAB}\end{array}$ & $1972 \mathrm{aB}$ & $2669 \mathrm{abAB}$ & $2717 \mathrm{aAB}$ & $2701 \mathrm{aAB}$ \\
\hline $40 \%$ & $2693 \mathrm{aAB}$ & $2874 \mathrm{aA}$ & $2770 \mathrm{aAB}$ & $\begin{array}{l}2740 \\
\mathrm{aAB}\end{array}$ & $2032 \mathrm{aB}$ & $2470 \mathrm{abAB}$ & $2777 \mathrm{aAB}$ & $2596 \mathrm{aAB}$ \\
\hline \multirow[t]{2}{*}{$20 \%$} & $2762 \mathrm{aA}$ & $2808 \mathrm{aA}$ & $2760 \mathrm{aA}$ & $2393 \mathrm{aA}$ & $1349 \mathrm{aB}$ & $2151 \mathrm{bAB}$ & $2347 \mathrm{aA}$ & $2237 \mathrm{aA}$ \\
\hline & \multicolumn{8}{|c|}{ Fv } \\
\hline $80 \%$ & $2126 \mathrm{aA}$ & $2288 \mathrm{aA}$ & $2244 \mathrm{aA}$ & $2368 \mathrm{aA}$ & 1211abB & $2365 \mathrm{aA}$ & $2372 \mathrm{aA}$ & $2138 \mathrm{aA}$ \\
\hline $60 \%$ & $2240 \mathrm{aA}$ & $2263 \mathrm{aA}$ & $2351 \mathrm{aA}$ & $2100 \mathrm{aA}$ & $1602 \mathrm{aA}$ & $2139 \mathrm{abA}$ & $2183 \mathrm{aA}$ & $2168 \mathrm{aA}$ \\
\hline $40 \%$ & $2094 \mathrm{aA}$ & $2313 \mathrm{aA}$ & $2200 \mathrm{aA}$ & $2198 \mathrm{aA}$ & $1640 \mathrm{aA}$ & $1924 \mathrm{abA}$ & $2233 \mathrm{aA}$ & $2067 \mathrm{aA}$ \\
\hline \multirow[t]{2}{*}{$20 \%$} & $2187 \mathrm{aA}$ & $2265 \mathrm{aA}$ & $2182 \mathrm{aA}$ & $1855 \mathrm{aA}$ & $945 \mathrm{bB}$ & $1604 \mathrm{bAB}$ & $1798 \mathrm{aA}$ & $1702 \mathrm{aAB}$ \\
\hline & \multicolumn{8}{|c|}{ Fv/Fm } \\
\hline $80 \%$ & $0.779 \mathrm{aA}$ & $0.799 \mathrm{aA}$ & $0.805 \mathrm{aA}$ & $0.811 \mathrm{aA}$ & $0.795 \mathrm{aA}$ & $0.814 \mathrm{aA}$ & $0.815 \mathrm{aA}$ & $0.801 \mathrm{aA}$ \\
\hline $60 \%$ & $0.773 \mathrm{aA}$ & $0.795 \mathrm{aA}$ & $0.797 \mathrm{aA}$ & $0.790 \mathrm{aA}$ & $0.808 \mathrm{aA}$ & $0.801 \mathrm{abA}$ & $0.802 \mathrm{aA}$ & $0.803 \mathrm{aA}$ \\
\hline $40 \%$ & $0.777 \mathrm{aA}$ & $0.805 \mathrm{aA}$ & $0.792 \mathrm{aA}$ & $0.801 \mathrm{aA}$ & $0.802 \mathrm{aA}$ & $0.746 \mathrm{abA}$ & $0.804 \mathrm{aA}$ & $0.795 \mathrm{aA}$ \\
\hline $20 \%$ & $0.791 \mathrm{aA}$ & $0.806 \mathrm{aA}$ & $0.790 \mathrm{aA}$ & $0.773 \mathrm{aA}$ & $0.689 \mathrm{bB}$ & $0.735 \mathrm{bAB}$ & $0.765 \mathrm{aAB}$ & $0.760 \mathrm{aAB}$ \\
\hline
\end{tabular}

\section{DISCUSSION}

Water deficit is a major problem worldwide, reducing plant yield in both agricultural and natural environments [7, 23, 24]. While the effect of water deficit on plants has been well studied, each species exhibits different mechanisms to overcome this stress factor. In the present study, severe stress (20\% FC) affected growth, paralyzing plant height and stem diameter and causing the leaves to shed in H. speciosa. Shedding was followed by the emission of new leaves, but to a lesser extent. This demonstrates that a severe reduction in soil moisture affects the processes of cell division and elongation [6, 25]. Interestingly, the onset of differences in plant height occurred only after 30 days of treatment and the plants remained nearly 22 days without watering until the field capacity reached 20\%. Moreover, plants grown under 60\% FC demonstrated a better performance in comparison to $40 \% \mathrm{FC}$, confirming the better growth of this species in well drained soils. Thus, mild stress favored the growth of the H. speciosa seedlings.

The dry matter yield of the stem and roots was not severely affected by water stress, as no significant differences were found among the treatments. In contrast, leaf dry matter and total dry matter were markedly reduced. These findings demonstrate the shedding of leaves induced by water deficit and also suggest variability among individuals with regard to dry matter production in each treatment. A reduction in dry matter generally reflects less carbon assimilation [26]. Although gas exchange was not evaluated in the present study, it is possible that stomatal conductance had been reduced in the plants under severe stress.

The data found on dry matter production reflect a change in the pattern of biomass partitioning in plants under $20 \% \mathrm{FC}$, with an increase in root dry matter in detriment to the shoot, reducing the shoot to root dry matter ratio to $1: 1$, whereas this ratio was approximately $5: 1$ in the control 
plants. These findings suggest that plants experiencing drought maximized biomass partitioning to root growth, while carbon assimilation in the shoot was used more to maintain previously formed structures. The deepening of the root system allows plants to find water in deeper regions of the soil. This behavior is considered a xeromorphic characteristic [4, 25], which allows plants to maintain the inflow of water and adequate water status.

Reduced growth as a survival strategy has been reported by Silva et al. (2010) [27] for seedlings of Erythrina velutina Willd, known locally as "mulungu". The authors found that, despite the absence of change in the dry matter distribution pattern, the reduction in growth allowed the seedlings to maintain turgor pressure. Indeed, the reduction in plant growth parameters is both a strategy and consequence. The control of the loss of water through transpiration by partially or completely closing the stomata during times of high temperature and in response to a low degree of soil water availability allows better water management, but, as a consequence, the inflow of $\mathrm{CO}_{2}$ is insufficient to maintain the structures and physiological processes for the synthesis of the carbon skeleton to maintain growth in height and new structures. Thus, smaller plants need less water to maintain functional processes and keep the cells hydrated [27].

Regardless of the differences found among treatments, the $H$. speciosa seedlings had high degrees of branch water potential even in situations of severe water stress $(-0,12 \mathrm{MPa}$ to treatment $20 \%$ FC), with higher values in comparison to those reported for other plant species. In Malpighia emarginata DC, known locally as "acerola", $\Psi \mathrm{w}$ of $-4.3 \mathrm{MPa}$ was found in plants propagated by seeds after five days of withholding water and $-4.5 \mathrm{MPa}$ was found in grafted plants after 20 days of withholding water [28]. Silva et al. (2003) [29] found a reduction in $\Psi_{\mathrm{w}}$ from -0.34 MPa to $0.87 \mathrm{MPa}$ in Mimosa caesalpiniifolia grown with 50\% FC. Several other species with anisohydric behavior experience a reduction in water potential under conditions of water stress, such as soybean, sunflower and wheat [30]. Silva et al. (2009) [31] classify Spondias tuberosa Arruda as an isohydric species due to the little variation in leaf water potential despite the reduction in soil moisture. Although further studies are necessary to determine the type of behavior $\mathrm{H}$. speciosa seedlings use to overcome water deficit, the present findings also suggest isohydric behavior. Studies performed under field conditions show that the mangabeira exhibits little variation in branch water potential throughout the year (unpublished data). The present investigation was performed in pots, in which low soil moisture is more evident than in the field, with $1.21 \%$ of soil moisture for plants with $20 \% \mathrm{FC}$ and $12.69 \%$ for control plants (data not shown). This low soil moisture may explain the small difference in branch water potential in stressed plants.

Regarding RWC, no significant differences were found among treatments and the values demonstrate that the species maintained the tissue hydrated. As water potential was only slightly reduced and RWC was not significantly affected, the reduction in growth in plants cultivated with $20 \%$ FC seems to be the strategy for overcoming severe water deficit and maintaining water status in the tissues.

Photochemical inhibition is often found in plants under severe stress. Drought can induce alterations in photobiological components, such as the reaction centers of PSI and PSII, thereby compromising photosynthesis efficiency $[7,14]$. H. speciosa seedlings exhibited little variation in photochemical parameters in the present study. Bacarin and Mosquim (2002) [32] stated that changes in fluorescence can occur as a result of plant growth.

A decrease in quantum efficiency occurred after 30 days of treatment. The value of 0.69 at this evaluation time is indicative of photoinhibition and was followed by a recovery to values reaching 0.74 and 0.76 in the two subsequent evaluations. These data suggest that the structure of PSII was unaffected by mild to moderate stress, but momentarily affected by severe stress (20\% FC), indicating a possible adjustment of the plants to stress conditions, with transient or dynamic photoinibition and subsequent recovery. Transient photoihibition generally occurs under natural conditions in times of high solar radiation, such as midday. By the end of the experimental period, the photochemical stage of photosynthesis did not appear to have been affected by the water stress applied. Values of Fv/Fm from 0.75 to $0.85[15,33]$ indicate that the PSII is intact, as such values are not found in plants subjected to severe stress.

Under stress, a decrease in the $\mathrm{Fv} / \mathrm{Fm}$ ratio has been attributed to the inactivity of reaction centers due to the degradation of D1 and D2 proteins, which are responsible for the transfer of 
electrons to chlorophyll $a$ associated with the PSII reaction center [34]. Thus, the lack of a reduction in the $\mathrm{Fv} / \mathrm{Fm}$ ratio in the $H$. speciosa seedlings under different water deficit treatments indicates an absence of harm to the protein structures of the photochemical complexes of the thylakoid membranes. Therefore, the capacity of plastoquinone complexes, which are responsible for the photochemical transport of electrons between PSI and II, to carry out oxidoreduction reactions may not have been affected by the mild, moderate and severe water stress applied.

The accumulation of osmotically active solutes is another tool for studying tolerance to water stress. Organic compounds (carbohydrates, amino acids and soluble proteins) and quaternary ammonium compounds as glycine betaine play an important role as osmoregulators and osmoprotectants $[11,18,35]$. The solutes studied in the present investigation were not significantly accumulated as a response to water deficit (Figure 6). However, the amount of proline accumulated in plants subjected to $60 \% \mathrm{FC}\left(8.35 \mu \mathrm{mol} \mathrm{g} \mathrm{g}^{-1} \mathrm{FM}\right)$ was approximately twofold greater than that in the control plants $\left(4.39 \mu \mathrm{mol} \mathrm{g}^{-1} \mathrm{FM}\right)$ (Figure 7). Moreover, plants submitted to moderate to severe water deficit ( $40 \%$ and $20 \%$ FC) exhibited a tendency toward the accumulation of proline, although the difference in comparison to control plants was nonsignificant. The level of intracellular proline is determined by biosynthesis, catabolism and transport between cells and different cellular compartments and has been associated with drought tolerance in plants [36]. As there were no changes in RWC or any significant reduction in water potential when cultivated under mild stress $(60 \% \mathrm{FC})$, the results suggest a role for proline other than osmoregulation in $H$. speciosa seedlings. Indeed, the increase in proline concentration may be related to the maintenance of the integrity of membranes and macromolecules through the removal of radical oxygen species; or perhaps proline plays a role in the regulation and control of plant development or as a signaling molecule [36, 37], since there was no indication of osmotic adjustment in response to drought in the present study.

Although carbon fixation was not studied in the present investigation, the results suggest that the reduction in growth under water deficit could be a consequence of strong stomatal control, which reduces the input of $\mathrm{CO}_{2}$ for photosynthetic assimilation and reduces the availability of carbon skeleton for vegetative growth. This reduction in stomatal opening, however, assists in maintaining the water content in the tissue, thereby avoiding desiccation. Further studies are needed about gas exchange to gain a better understanding of the mechanism used by H. speciosa seedlings under water deficit. In the present study, these seedlings tolerated drought with high water potential and a change in the growth pattern, with a decrease in the shoot to root ratio. This change seems to be the strategy for maintaining water status and the survival of the species under conditions of severe water stress.

\section{CONCLUSION}

The change in growth pattern, with an increase in root depth and a reduction in shoot emission, seems to be the main strategy of mangabeira seedlings for maintaining tissue hydration and tolerating severe water deficit throughout the period of imposed water stress.

\section{ACKNOWLEDGMENT}

The authors would like to thank the Fundação de Amparo a Pesquisa e Inovação Tecnológica do Estado de Sergipe (FAPITEC-SE) for financial support (No. 019.203.02212/2009-4) and Mr. Richard Boike for the English corrections.

\section{REFERÊNCIAS BIBLIOGRÁFICAS}

1. Lorenzi H, Souza VC. Botânica sistemática: Guia ilustrado para identificação das famílias de Fanerógamas nativas e exóticas no Brasil, baseado no APG II. 2nd ed. Nova Odessa: Instituto Plantarum; 2008. 704 p. 
2. Vieira Neto RD, Cintra FLD, Ledo AS, Silva Junior JF, Costa JLS, Silva AAG, Cuenca MAG. Sistema de produção de mangaba para os tabuleiros costeiros e baixada litorânea. Aracaju (SE): Embrapa Tabuleiros Costeiros; 2002. 22 p.

3. Soares FP, Paiva R, Nogueira RC, Oliveira LM, Silva DRG, Paiva PDO. Cultura da mangabeira (Hancornia speciosa Gomes). Bol Agropec. 2006; 67:1-12.

4. Larcher W. Ecofisiologia Vegetal. São Carlos: RiMa; 2000. 531 p.

5. Silva EC, Nogueira, RJMC, Silva MA, Albuquerque MB. Drought stress and plant nutrition. Plant Stress. 2011; 5(1):32-41.

6. Taiz L, Zeiger E. Plant Physiology. 4th ed Sunderland (MA): Sinauer Associates Inc. 2006. 764 p.

7. Silva EC, Albuquerque MB, Azevedo Neto AD, Silva Junior CD. Drought and its consequences to the plants: from individual to ecosystems. In: Akinci S, editor, Responses of organisms to water stress, Croatia: InTech. 2013. p.17-47, doi: 10.5772/53833

8. Kozlowski TT, Pallardy SG. Acclimation and Adaptive Responses of Woody Plants to Environmental Stresses. Bot Rev. 2002; 68(2): 270-334, doi:10.1663/0006-8101(2002)068[0270:AAAROW]2.0.CO;2

9. Pinheiro HA, DaMatta FM, Chaves ARM, Loureiro ME. Drought tolerance is associated with rooting depth and stomatal control of water use in clones of Coffea canephora. Ann Bot. 2005; 96: 101-108, doi: 10.1093/aob/mci154

10. Hong-Bo F, Xiao-Yan C, Li-Ye C, Xi-Ling Z, Gang W, Yong-Bing Y, Chang-Xing Z, Zan-Min H. Investigation on the relationship of proline with wheat anti-drought under soil water deficits. Colloids Surf B. 2006; 53:113-119, doi:10.1016/j.colsurfb.2006.08.008

11. Ashraf M, Foolad MR. Roles to glycine betaíne and proline in improving plant abiotic stress ressssistence. Environ Exp Bot. 2007; 59:206-216, doi:10.1016/j.envexpbot.2005.12.006

12. Chen H, Jiang JG. Osmotic adjustment and plant adaptation to environmental changes related to drought and salinity. Environ. Rev. 2010; 18:309-319, doi: 10.1139/A10-014

13. Maxwell K, Johnson GN. Chlorophyll Fluorescense - a practical guide. J Exp Bot. 2000; 51(345): 659668, doi: 10.1093/jexbot/51.345.659

14. Angelopoulos K, Dichio B, Xiloyannis C. Inhibition of photosynthesis in olive trees (Olea europaea L.) during water stress and rewatering. J Exp Bot. 1996; 47:1093-1100, doi: 10.1093/jxb/47.8.1093

15. Bolhàr-Nordenkampf HR, Long SP, Baker NR, Öquist G, Schreiber U, Lechner EG (1989) Chlorophyll fluorescence as a probe of the photosynthetic competence of leaves in the field: A review of current instrumentation. Funct Ecol. 1989; 3:497-514, doi: 10.2307/2389624

16. Souza CC, Oliveira FA, Silva IF, Amorim Neto MS. Avaliação de métodos de determinação de água disponível e manejo da irrigação em terra roxa sob cultivo de algodoeiro herbáceo. Rev Bras Eng Agríc Amb. 2000;4(3): 338-342, doi: 10.1590/S1415-43662000000300006

17. Weatherley PE. Studies in the water relations of the cotton plant. I- The field measurements of water deficits in leaves. New Phytologist. 1950; 49:81-97, doi:10.1111/j.1469-8137.1950.tb05146.x

18. Azevedo Neto AD, Nogueira RJMC, Melo Filho, PA, Santos RC. Physiological and biochemical responses of peanut genotypes to water deficit. J Plant Inter. 2009; 5:1-10, doi: $10.1080 / 17429140902999243$

19. Dubois M, Gilles KA, Hamilton JK, Rebers PA, Smith F. Colorimetric method for determination of sugars and related substances. Anal. Chem.1956; 28:350-356, doi: 10.1021/ac60111a017

20. Bates LS. Rapid determination of free proline for water-stress studies. Short communication. Plant Soil. 1973; 39:205-207, doi: 10.1007/BF00018060

21. Bradford MM (1976) A rapid and sensitive method for the quantitation of microgram quantities of protein utilizing the principle of protein-dye binding. Anal Biochem. 1976; 72:248-254, doi: 10.1016/0003-2697(76)90527-3

22. Rhee KH, Morris EP, Barber J, KuÈhlbrandt W. Three-dimensional structure of the plant photosystem II reaction centre at $8 \AA$ A resolution. Nature. 1998. Nov; 396:283-286, doi:10.1038/24421

23. Valliyodan B, Nguyen HT. Understanding regulatory networks and engineering for enhanced drought tolerance in plants. Curr Opin Plant Biol. 2006; 9(2):189-195, doi: 10.1016/j.pbi.2006.01.019

24. Anjum SA, Xie X, Wang L, Saleem MF, Man C, Lei W. Morphological, physiological and biochemical responses of plants to drought stress. Afr J Agric Res. 2011; 6(9):2026-2032, doi: 10.5897/AJAR10.027

25. Jaleel CA, Manivannan P, Wahid A, Farooq M, Al-Juburi HJ, Somasundaram R, Panneerselvam R. Drought stress in plants: a review on morphological characteristics and pigments composition. Int $\mathbf{J}$ Agric Biol. 2009; 11:100-105.

26. Farooq, M., Wahid A, Kobayashi N, Fujita D, Basra SMA. Plant drought stress: effects, mechanisms and management. Agron Sustain Dev. 2009; 29: 185-212, doi: 10.1051/agro:2008021

27. Silva EC, Silva MFA, Nogueira RJMC, Albuquerque MB. Growth evaluation and water relations of Erythrina velutina seedlings in response to drought stress. Braz. J Plant Physiol. 2010; 22(4) 225-233, doi: 10.1590/S1677-04202010000400002 
28. Nogueira RJMC, Moraes JAPM, Burity HA, Bezerra Neto E. Alterações na resistência à difusão de vapor das folhas e relações hídricas em aceroleiras submetidas a déficit de água. Rev Bras Fisiol Veg. 2001; 13(1):75-87, doi: 10.1590/S0103-31312001000100009

29. Silva EC, Nogueira RJMC, Azevedo Neto AD, Santos VF. Comportamento estomático e potencial da água da folha em três espécies lenhosas cultivadas sob estresse hídrico. Acta Bot Bras. 2003; 17(2): 231-246, doi: 10.1590/S0102-33062003000200006

30. Tardieu F, Simonneau T. Variability among species of stomatal control under fluctuating soil water status and evaporative demand: modelling isohydric and anisohydric behaviours. J Exp Bot. 1998; 49:419:432, doi: 10.1093/jxb/49.Special_Issue.419

31. Silva EC, Nogueira RJMC, Vale FHA, Melo NF, Araujo FP. Water relations and organic solutes production in four umbu tree (Spondias tuberosa) genotypes under intermittent drought. Braz J Plant Physiol. 2009; 21(1): 43-53, doi: 10.1590/S1677-04202009000100006

32. Bacarin MA, Mosquim PR. Cinética de emissão de fluorescência das clorofilas de dois genótipos de feijoeiro. Rev. Ciên. Agrotec. 2002; 26 (4):705-710.

33. Bjorkman O, Demmig B. Photon yield of O2 evolution and chlorophyll fluorescence characteristics at 77 K among vascular plants of diverse origins. Planta. 1987; 170:489-504, doi: 10.1007/BF00402983

34. Lazar D. Chlorophyll a fluorescence rise induced by high light illumination of dark adapted plant tissue studied by means of photosystem II and considering photosystem II heterogeneity. J Theor Biol 2003; 220:469-503, doi: 10.1006/jtbi.2003.3140

35. Hare PD, Cress WA, Van Staden J. Dissecting the roles of osmolyte accumulation during stress. Plant Cell Environ. 1998; 21:535-553, doi: 10.1046/j.1365-3040.1998.00309.x

36. Szabados L, Savoure' A. Proline: a multifunctional amino acid. Trends Plant Sci. 2009; 15(2): 89-97, doi: 10.1016/j.tplants.2009.11.009

37. Mattioli R, Costantino P, Trovato M. Proline accumulation in plants not only stress. Plant Signal Behav. 2009; 4(11):1016-1018. 